\title{
Changes of the Employees' Flow in Transport and Hospitality in COVID-19 Times - a Measure of Resilience
}

\author{
Cristina Lincaru ${ }^{1}$, Adriana Grigorescu ${ }^{2}$ and Speranța Pîrciog ${ }^{3}$ \\ ${ }^{133)}$ National Scientific Research Institute for Labor and Social Protection-INCSMPS, \\ Bucharest, Romania. \\ 2) National University of Political Studies and Public Administration \& Correspondent \\ Member of the Romanian Scientists Academy, Bucharest, Romania. \\ E-mail: cristina.lincaru@yahoo.de; E-mail: adriana.grigorescu@snspa.ro \\ E-mail: pirciog@incsmps.ro
}

\begin{abstract}
Please cite this paper as:
Lincaru, C., Grigorescu, A. and Pîrciog, S., 2021. Changes of the Employees' Flow in Transport and Hospitality in CovID-19 Times - a Measure of Resilience. In: R. Pamfilie, V. Dinu, L. Tăchiciu, D. Pleșea, C. Vasiliu eds. 2021. 7th BASIQ International Conference on New Trends in Sustainable Business and Consumption. Foggia, Italy, 3-5 June 2021. Bucharest: ASE, pp. 261-267 DOI: 10.24818/BASIQ/2021/07/034
\end{abstract}

\begin{abstract}
Our paper proved the efficiency of an instrument that can be applied to quickly evaluate the labour market response to COVID 19 measures. The prevention measures, imposed with the objective to protect the lives and the wellbeing of the workers, act as interventions on labour market with direct effect toward increasing its rigidity. The worker flows' (the sum of hiring and dismissal) decrease indicate a lower rate of new job creation based on innovation adoption, and the increasing the dismissal flows. Both situations indicate a low sustainability for employment.

We explore the workers' mobility across EU27 and 13 NACE Rev 2 economic sectors by analyzing the rates of: hiring, dismissal, employment growth, total workers reallocation and excess workers reallocation. We apply the model (Lincaru, et al., 2011; Lincaru, et al., 2012) following (OECD, 2010, 2009) methodology consistent with (Davis and Haltiwanger, 1999), using micro aggregated data of Eurostat during 2018-2020 period.

Transport and hospitality economic sectors are among the most affected ones. Post COVID, these sectors are expected to shrink, slowing down the increasing productivity growth and innovation adoption, decrease the quality of employment, diminish the speed of skill allocation, and block the youth entrance. The hospitality industry (I) has the highest gross worker flow among the EU27 sectors, fact that confirms its competitive position. Hospitality is a driver sector for transport demand. Its increasing risk to lose workers, coupled with labour deficit, raises important challenges for the European economy competitiveness. The persistence of the Covid pandemic has direct impact on the labour market, with consequences such as severe decrease of hiring and austere increase of dismissal. The existence of a threshold would determine higher resilience of the sectors in discussion.
\end{abstract}

\section{Keywords}

Worker flows, hiring, dismissal, resilience, worker reallocation, transport, hospitality.

DOI: 10.24818/BASIQ/2021/07/034

\section{Introduction}

The paper suggests the usage of hirings as inputs on the labour market, and dismissals as exit from work events, through the measuring of the interactions between firms and workers. The reference for transition is the employment status and not the job. To have a picture of the activities' constriction determined by the COVID 19 pandemic, we calculated the 2018, 2019, and 2020 annual rates for the employee flows: hiring, dismissal, total reallocation, and excess reallocation. Some sectors were 
affected by the lockdown restriction as a measure of health protection. The health crisis hit the world economies with long-term effects, and various intensity levels per sector. The transport and hospitality sectors were the hardest affected, and we considered that the variation of the employees' flows could illustrate the resilience characteristics.

Diodato and Weterings (2015) found on Dutch data that the high-speed recovery, irrespective of the type of shock, is observable in the economies of the service-oriented regions and centrally located regions. Futhermore, the dimension of the worker flows is essential for the unemployment policy debate. On the other hand, Elsby, et al. (2011) found that the nature of the job lost is the main point of the appropriate response. The resilience is under question in the analyzed sectors, since the pandemic persistence and intensity is longer than expected. On-line working and teleworking was a solution to overcome the restrictions and to sustain the business (Grigorescu and Mocanu, 2020). Moreover, the social protection and the governmental measures has to be considered in the extreme situations (Iordan, et al., 2014; Mina, 2021).

\section{Review of the scientific literature}

Davis and Haltiwanger (1999) compared the registered status at two moments in time ( $\mathrm{t}$ and $\mathrm{t}-1)$. They considered:

- $\quad$ Hirings $=$ the number of employees in the firm at time $t$, but no longer employed at time $t-1$.

- $\quad$ Dismissals $=$ the number of employees in the firm at $\mathrm{t}-1$, but not at $\mathrm{t}$.

- Gross job reallocation (gross job turnover) = the absolute value of the net change in employment between two moments in time. (Davis and Haltiwanger, 1992, 1999; Davis et al., 1996; and OECD, 1996).

Following this terminology, at the individual firm's level, job creation is equal to the net employment change if the latter is positive, or, otherwise, zero. Conversely, job destruction is similar to the net change's absolute value if the latter is a negative sign, or zero otherwise. Job reallocation, job creation, and job destruction are gross job flows, that differentiate themselves from the more familiar net employment growth measures. Net and gross job flows coincide at the level of a single firm, but that is no longer the case when considering groups of firms.

Hamermesh, et al. (1994) identified a "concomitant heterogeneity in flows of workers into and out of the firm, and through and between jobs, among firms whose employment is changing at identical rates". Hamermesh (1989) examined the costs firms face in adjusting labour demand to exogenous shocks. Bekker et al. (2008) defined the external numerical flexibility, i.e. the ease of "hiring and firing" which manifests itself in workers' mobility between employers (external job turnover).

Kramarz and Michaud (2010) point out that theoretical models (Bentolila and Bertola, 1990; Bertola, 1990; Garibaldi, 1998, etc.) prove that "stringent legislation reduces hiring and firing, but also affects the structure of unemployment".

We explore some empirical questions, using micro aggregated Eurostat data for EU27, as ,a prerequisite for assessing the role of policies in shaping worker flows" (OECD, 2009) in the COVID 19 pandemic, during 2018-2020 period:

Q1. What are the hiring and firing rates in absolute levels compared to other sectors for the $\mathrm{H}$ (Transportation and storage) and I (Accommodation and food service activities)?

Q2. How large is the reallocation of workers in H and I sectors compared to other sectors?

\section{Research methodology}

We apply the model (Lincaru, et al., 2011; Lincaru, et al., 2012) following (OECD, 2010, 2009) methodology consistent with (Davis and Haltiwanger, 1999). The annual hiring flows counts the Eurostat's quarterly employment, and is used as a proxy for employment by job tenure.

The worker flows approach to consider the job flows essentially reflect the reallocation driven by labour demand. Those are the result of a mix of factors playing on the labor market (demand, supply), which 
depend on both firm and worker characteristics (OECD, 2009). The model considered events as input /output time intervals. Consequently, hiring and separations are transition effects from any status to / out employment between two moments in time, $t-1$ and $t$.

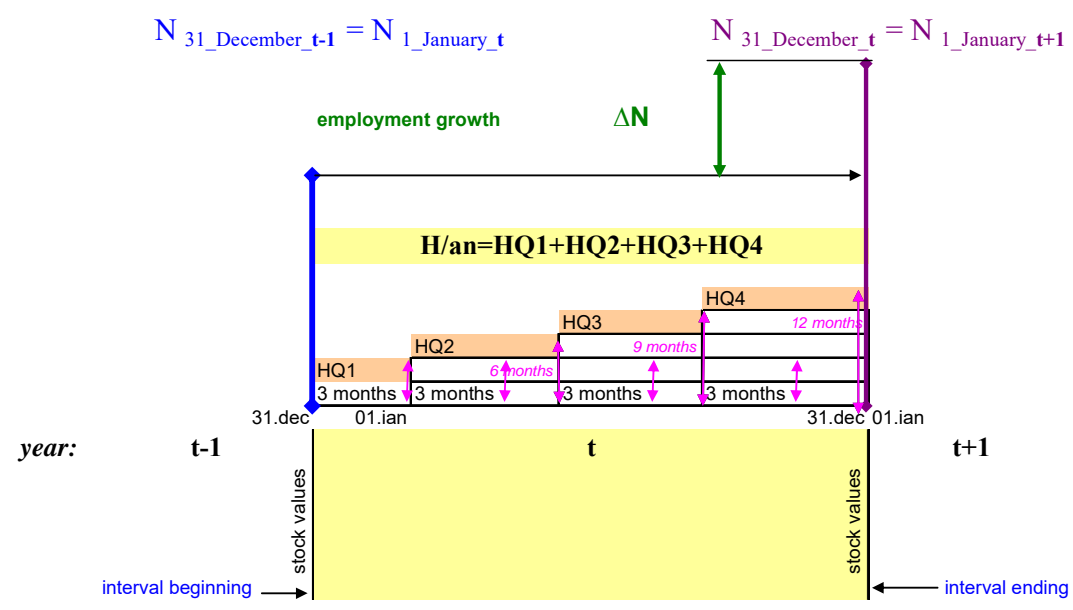

Figure no. 1. Flow indicators and stock indicators used in the worker flow measurement - logical scheme based on EUROSTAT metadata

Source: Lincaru, et al., 2011

As it is presented in Figure 1, the hiring as a flow indicator $\left(H_{[t-1: t]}\right)$ is calculated as:

$$
\left.H_{[} \mathbf{t}-1: t\right]=H_{Q 1}+H_{Q 2}+H_{Q 3}+H_{Q 4}
$$

Workers' total reallocation represents the sum of workers' number with events of hiring $\left(H_{[t-1: t]}\right)$ and firing $\left(S_{[t-1: t]}\right)$ during a one-year interval:

$$
T R N_{[t-1: t]}=H_{[t-1: t]}+S_{[t-1: t]}
$$

Furthermore, the workers' excess reallocation represents the workers' reallocation between firms from the same industry" (OECD 2009, pg.122) and the absolute modification of the net employment indicates the reallocation measure between different groups of firms / various sectors, during a oneyear interval;

$$
E R N_{[t-1: t]}=T R N_{[t-1: t]}-\left|\Delta N_{[t-1: t]}\right|
$$

where:

$$
\Delta N_{[t-1: t]}=H_{[t-1: t]}-S_{[t-1: t]}=N t-N t-1
$$

$\Delta N_{[t-1: t]}=$ Annual employment changes;

Based on the mentioned definition, were calculated the following indicators: the $r H_{[t-1: t]}=$ annual rate of workers' hiring, the $r S_{[t-1: t]}=$ annual rate of workers' firing, and $r T R N_{[t-1: t]}=$ annual rate of workers total reallocation.

\section{Data and indicators}

The data used to for the model comprises of:

a) The quarterly number of employed persons in a national area, Eurostat source: "Employment by sex, age, time since job started and economic activity (from 2008 onwards, NACE Rev. 2) - 1000 [lfsq_egdn2] intern - DURATION: Total, SEX: Total AGE: From 15 to 64 years";

b) And the quarterly number of employed persons for less than 3 months since the job started, Eurostat source: "Employment by sex, age, time since job started and economic activity (from 2008 onwards, NACE Rev. 2) - 1000 [lfsq_egdn2], DURATION: Less than 3 months, Total, SEX: Total AGE: From 15 to 64 years". 
The economic sectors highlighted in this study are $\mathrm{H}$ - Transportation and storage, and I Accommodation and food service activities of the 13 sectors considered (A-R). To compare the effect of the COVID-19 pandemic, the considered years were 2018, 2019, and 2020.

\section{Results and discussion}

\section{- Hiring rate decreases regardless of the sector, and evident in almost all countries:}

Since COVID-19 started Hiring rates showcased decreases for all sectors at EU27 level in 2020/2019, with -2.2pp compared to 2019/2018 with $\mathbf{- 0 . 3}$ pp. There was a 7 times hiring rate decrease registered after the health crisis spread at global level. Both I and H sectors decreased more than the EU27 average. I sector was the second affected, with a registered decrease of -7.2pp in 2020/2019, compared to -0.3 in $2019 / 2018$, and $\mathrm{H}$ the fifth affected, with a registered decrease of $-3,1 \mathrm{pp}$ in 2020/2019 compared to -1.7 in 2019/2018.

The $\mathbf{H}$ sector presented a homogenous hiring rate decreasing profile within the 12 countries included in the study. Sweden registered a -7,5pp decrease, above the EU27 average. UK managed the Pandemic shock in a balance, with a $0 \%$ change of hiring rates, while the Czech Republic was the only country reported with $+0.1 \%$ hiring rate.

The I sector confirms the same tendency of hiring rate decreasing profile, for 13 countries from the 15 included in the study, with an average of 3.1 for EU27. Finland, Sweden, Spain, the Netherlands, Cyprus, Italy, and UK have had a decrease above the EU27 average, from -16.3 pp to $-7.5 p p$, while Austria and Germany faced the pandemic shock in a balance, with a $+0.5 \%$ change of hiring rates. Hungary was the only country to report a significant $+2.8 \%$ hiring rate.

Table no. 1. Hiring rates' change from $2020 / 2019$ and 2019/2018

\begin{tabular}{|c|c|c|c|c|}
\hline SECT & rH18 & rH19 & rH20 & $\begin{array}{c}d r H \\
2019\end{array}$ \\
\hline $\mathbf{J}-$ Information and communication & 61.3 & 56.9 & 41.6 & -15.3 \\
\hline I - Accommodation and food service activities & 38.5 & 36.8 & 29.5 & -7.2 \\
\hline $\mathbf{R}-$ Arts, entertainment and recreation & 26.6 & 26.4 & 21.4 & \\
\hline $\mathbf{N}-$ Administrative and support service activities & 24.9 & 23.7 & 19.5 & -4.2 \\
\hline $\mathrm{H}$ - Transportation and storage & $\mathbf{1 7 . 5}$ & 17.2 & 14.1 & -3.1 \\
\hline $\mathbf{F}-$ Construction & 20.0 & 19.1 & 16.8 & -2.3 \\
\hline EU27 & $\mathbf{1 7 . 5}$ & 17.2 & 15.0 & -2.2 \\
\hline $\mathbf{M}$ - Professional, scientific and technical activities & 14.7 & 15.3 & 13.4 & -2.0 \\
\hline $\mathbf{K}-$ Financial and insurance activities & 19.3 & 20.2 & 18.3 & -1.9 \\
\hline C - Manufacturing & 14.1 & 12.9 & 11.1 & -1.8 \\
\hline $\mathbf{P}$ - Education & 14.5 & 14.5 & 13.2 & -1.4 \\
\hline Q- Human health and social work activities & 16.1 & 16.0 & 15.0 & -1.0 \\
\hline A - Agriculture, forestry and fishing & 16.6 & 17.2 & 16.5 & -0.7 \\
\hline $\begin{array}{l}\text { O - Public administration and defence; compulsory } \\
\text { social security }\end{array}$ & 9.6 & 10.0 & 9.5 & -0.6 \\
\hline
\end{tabular}

\begin{tabular}{|l|r|r|r|r|}
\hline Max & 61.3 & 56.9 & 41.6 & $\mathbf{- 1 5 . 3}$ \\
\hline Min & 9.6 & 10.0 & 9.5 & $\mathbf{- 0 . 6}$ \\
\hline StDev & 13.74 & 12.50 & 8.63 & $\mathbf{- 3 . 8 8}$ \\
\hline
\end{tabular}

Source: Data calculated by authors.

\section{- Firing rates present the general tendency to increase in 2/3 of sectors and countries:}

Firing rates increased in 2020 compared to 2019, in 7/12 sectors at EU27 level, the average increase accounting for $0.1 \mathrm{pp}$. Compared to $2019 / 2018$ when the rate decreased with $0.7 \mathrm{pp}$, it is obvious that before the pandemic the enterprises were keeping their employees; hence, the health crisis was the major determinant for the explosion of the dismissal phenomenon. The most affected sector was $\mathrm{F}$, with the maximum increase of 5.6pp, compared with J, the less affected sector. Both I and $\mathrm{H}$ sectors increased more than the EU27 average. I is the second affected sector as a result of lockdown and restrictions, while $\mathrm{H}$ registered the forth increase, mainly as a consequence of travelling restrictions. 
The $\mathbf{H}$ sector presented an increase of the firing rates of $2.5 \mathrm{pp}$, within the 12 countries included in the study. Czech Republic and Belgium recorded the highest rates of $14.6 \mathrm{pp}, 11.8 \mathrm{pp}$ respectively, only a few times more than the average, while Spain, with $5.6 \mathrm{pp}$, had firing rates two times over the EU27 average. The Netherlands, Italy and Germany faced the Pandemic shock in a balance, with a $0 \%$ change of hiring rates. Remarkable is the positive tendency in UK, Sweden, France and Poland, all registering negative rates of dismissal.

The I sector was the second affected, and, from the profile of 15 analyzed countries, Cyprus, Austria, Finland and Hungary are having the highest rates, with levels of a few times more than the average. Spain, Italy and Germany faced the pandemic shock in a balance, and, surprisingly, Sweden and France firing rates consistently decreased (-7.5pp and $-9 \mathrm{pp})$.

Table no. 2. Firing rates change from 2020/2019 and 2019/2018

\begin{tabular}{|c|c|c|c|c|}
\hline SECT & rS18 & rS19 & rS20 & $\begin{array}{l}d r S \\
2019\end{array}$ \\
\hline $\mathbf{F}-$ Construction & 18.3 & 17.6 & 23.2 & 5.6 \\
\hline I - Accommodation and food service activities & 36.4 & 36.1 & 40.0 & 4.0 \\
\hline $\mathbf{N}$ - Administrative and support service activities & 23.2 & 22.4 & 26.0 & 3.7 \\
\hline H - Transportation and storage & 16.2 & 15.7 & 18.2 & 2.5 \\
\hline Q - Human health and social work activities & 14.8 & 14.0 & 15.4 & 1.4 \\
\hline $\mathbf{R}-$ Arts, entertainment and recreation & 25.6 & 23.2 & 24.1 & 0.9 \\
\hline $\mathbf{M}$ - Professional, scientific and technical activities & 12.8 & 12.5 & 13.0 & 0.5 \\
\hline $\mathbf{P}-$ Education & 12.6 & 12.8 & 13 & 0.2 \\
\hline EU27 & 16.5 & 16.3 & 16.4 & 0.1 \\
\hline A-Agriculture, forestry and fishing & 19.6 & 19.1 & 18.6 & -0.5 \\
\hline C-Manufacturing & 13.2 & 12.8 & 12.0 & -0.8 \\
\hline $\begin{array}{l}\text { O-Public administration and defence; compulsory social } \\
\text { security }\end{array}$ & 8.9 & 10.2 & 5.8 & -4.5 \\
\hline $\mathbf{K}$ - Financial and insurance activities & 19.8 & 20.8 & 15.5 & -5.3 \\
\hline $\mathbf{J}$ - Information and communication & 56.8 & 52.7 & 36.4 & -16.3 \\
\hline Max & 56.8 & 52.7 & 40.0 & -12.7 \\
\hline Min & 8.9 & 10.2 & 5.8 & -4.5 \\
\hline StDev & 12.78 & 11.73 & 9.77 & -1.97 \\
\hline
\end{tabular}

Source: Data calculated by authors.

- Annual rate of workers' total reallocation is a measure of external numerical flexibility. (Bekker et al., 2008)

Total reallocation rates mirror the summarized effect of hiring and firing in 2020 compared to 2019, as well as the pandemic impact. At EU27 level, the sectors registered a decrease of -2pp. J registered the maximum decrease of $-31.6 \mathrm{pp}$, while $\mathrm{F}$ recorded the maximum increase of $3.3 \mathrm{pp}$. H sector maintained a higher numerical external flexibility compared to I, as it slightly decreased, with $-0.5 \mathrm{pp}$, above the EU27 average, while I decreased with -3.3pp.

The $\mathbf{H}$ sector a decrease of $-0.5 \mathrm{pp}$ of the total reallocation rates, within the studied countries. The general tendency is the numerical external flexibility decrease, with the exception of Czech Republic and Belgium, which are the cases of over flexibility, source of unsustainable employment growth. Austria and Germany faced the pandemic crisis in a balanced scenario for total reallocation rates, with a $-0.6 p p,-0.5 p p$ respectively, close to the EU average. Sweden, Poland, and France have registered high decrease rates, over ten times than the EU27 average.

The I sector confirms the tendency of decreasing for total reallocation rates. The Netherlands, Spain, UK, France, and Sweden showcased a decreasing rate of $-11 \mathrm{pp}$ to $-20.2 \mathrm{pp}$, a few times over the EU27 sector average of $-3.3 \%$. Germany and Czech Republic registered a balance, with a rate of $0.4 \mathrm{pp}$, and $0.5 \mathrm{pp}$ change of total reallocation rates. On the other side, Austria and Hungary showcased an increase in the total reallocation rates of over $15 \mathrm{pp}$, process mainly driven by firing events, a reflection of unsustainable employment growth. 
Table no. 3. Total reallocation rates change from 2020/2019 and 2019/2018

\begin{tabular}{|c|c|c|c|c|}
\hline SECT & $\begin{array}{l}\text { rTR } \\
18\end{array}$ & $\begin{array}{l}\text { rTR } \\
19\end{array}$ & $\begin{array}{l}r T R \\
20\end{array}$ & $\begin{array}{l}d T R \\
2019\end{array}$ \\
\hline $\mathbf{F}-$ Construction & 38.3 & 36.7 & 40.0 & 3.3 \\
\hline Q - Human health and social work activities & 30.9 & 30.0 & 30.4 & 0.4 \\
\hline H - Transportation and storage & 33.7 & 32.8 & 32.3 & -0.5 \\
\hline $\mathbf{N}-$ Administrative and support service activities & 48.2 & 46.1 & 45.5 & -0.6 \\
\hline $\mathbf{P}-$ Education & 27.1 & 27.3 & 26.1 & -1.2 \\
\hline A-Agriculture, forestry and fishing & 36.2 & 36.3 & 35.1 & -1.2 \\
\hline $\mathbf{M}$ - Professional, scientific and technical activities & 27.5 & 27.9 & 26.4 & -1.5 \\
\hline EU27 & 34.0 & 33.5 & 31.4 & -2.0 \\
\hline C-Manufacturing & 27.3 & 25.7 & 23.0 & -2.7 \\
\hline I - Accommodation and food service activities & 74.9 & 72.9 & 69.6 & -3.3 \\
\hline $\mathbf{R}-$ Arts, entertainment and recreation & 52.3 & 49.5 & 45.4 & -4.1 \\
\hline $\begin{array}{l}\mathbf{O} \text { - Public administration and defence; compulsory } \\
\text { social security }\end{array}$ & 18.5 & 20.3 & 15.2 & -5.0 \\
\hline $\mathbf{K}-$ Financial and insurance activities & 39.1 & 41.0 & 33.8 & -7.2 \\
\hline $\mathbf{J}$ - Information and communication & 118.1 & 109.6 & 78.0 & -31.6 \\
\hline Max & 118.1 & 109.6 & 78.0 & -31.6 \\
\hline Min & 18.5 & 20.3 & 15.2 & -5.0 \\
\hline StDev & 26.49 & 24.19 & 17.89 & -6.31 \\
\hline
\end{tabular}

Source: Data calculated by authors.

Based on the definition of employment, we have to make some observations:

* the degree of generality is the highest. It covers the labour market in extended concept of employed person, and not only in reference to salaried person;

* the worker flows are strongly dependent on the main criteria that shapes the frontier of the job, as well as the borders of the firm (including the observation unit). Under the global competition, pressure is increasing the dependence on profit, focused on short-term objectives and diminishing the risk tolerance.

\section{Conclusions}

The first conclusion to be drown based on the hiring and dismissal annual rates for 2020 to 2019 and 2019 to 2018 is that the pandemic crisis, through the restriction imposed by the health security, significantly affected the employment and dismissal. Among the 15 economic sectors studied, there are consistent differences, as sector $\mathbf{J}$ - Information and communication, taking the 'star' status, of a flourishing sector in 2020 .

The $\mathrm{H}$ - Transportation and storage, and I - Accommodation and food service activities, sectors expressing the hospitality economic area, are among the most vulnerable. Considering the situation before 2020, those sectors were the most attractive and job creative sectors. Post Covid-19 crisis, these sectors shrinked, slowing down the increasing productivity growth and innovation adoption, decreased the quality of employment, diminished the speed of skill allocation, and blocked the youth entrance on the labour market. Hospitality sectors (I) still have the highest gross worker flow among the EU27 sectors, fact that confirms its competitiveness and potential. This sector is a driver for transport $(\mathrm{H})$ demand, while, in 2020, taking the form of a braking system due to the travel restrictions. Its increasing risk to lose workers, coupled with labour deficit, raises important challenges for the European economy competitiveness, and the recovering of the tourism industries (Škare et al., 2021, Aguiar-Quintana et al., 2021). A proper support from the government of the more affected countries could speed up the recovery of the hospitality sector in conjunction with policies of youth employment (Grigorescu, 2006).

\section{References}

Aguiar-Quintana, T., Nguyen, H., Araujo-Cabrera, Y. and Sanabria-Díaz, J. M., 2021. Do job insecurity, anxiety and depression caused by the COVID-19 pandemic influence hotel employees' self-rated task performance? The moderating role of employee resilience. International Journal of Hospitality Management, 94, Article number: 102868. 
Bekker, S., Wilthagen, T., Kongshøj Madsen, P., Zhou, J., Rogowski, R., Keune, M. and Tangian, A., 2008.

Flexicurity - a European Approach to Labour Market Policy. Intereconomics, 43, pp.68-111.

Davis, S. and Haltiwanger, J., 1999. Gross Job Flows. In Ashenfelter, O. and D. Card. Handbook of Labor Economics, Vol. 3, Elsevier, pp.2711-2805.

Diodato, D. and Weterings, A.B.R., 2015. The resilience of regional labour markets to economic shocks: Exploring the role of interactions among firms and workers. Journal of Economic Geography, 15, pp.723-742.

Elsby, M.W.L., Smith, J.C. and Wadsworth, J., 2011. The role of worker flows in the dynamics and distribution of UK unemployment. Oxford Review of Economic Policy, 27, pp.338-363.

Grigorescu, A. 2006. Marketing of public and private affairs-a link. Kybernetes, 35(7/8), pp.11791189.

Grigorescu, A. and Mocanu, A., 2020. Teleworking Perspectives for Romanian SMEs after the COVID-19 Pandemic. Management Dynamics in the Knowledge Economy, 8(4), Article number: 383.

International Institute for Labour Studies, 2011. Building a sustainable job-rich recovery. International Labour Organization, Geneva.

Iordan, M., Chilian, M.N. and Grigorescu, A., 2015. Regional Resilience in Romania-Between Realism and Aspirations. Procedia Economics and Finance, 22, pp.627-635.

Kramarz, F. and Michaud, M.L., 2010. The shape of hiring and separation costs in France. Labour Economics, 17, pp.27-37.

Lincaru, C., Ciucă, V. and Pîrciog, S., 2011. Alternative method of Gross worker flows measurementStudy case Romania. Conferința 23 EALE, Cipru 2011.

Lincaru, D.C., Ciucă, D.V., Atanasiu, M.D., Ghinararu, D.C., Tudose, D.G. and Grecu, L., 2012. Gross Worker Flows Estimation At European Level. Regional Science Inquiry IV, pp.95-104.

Mina, W., 2021. Do Labor Market Flexibility and Efficiency Increase Government Social Protection Expenditures? Applied Economics, pp.1-17.

OECD, 2010. Institutional and Policy Determinants of Labour Market Flows. In: OECD Employment Outlook 2010. [online] OECD.pp.167-210. https://doi.org/10.1787/empl_outlook-2010-4-en.

OECD, 2009. How Do Industry, Firm and Worker Characteristics Shape Job and Worker Flows? In: OECD Employment Outlook 2009. [online] OECD.pp.117-163. https://doi.org/10.1787/empl_outlook-2009-3-en.

Škare, M., Soriano, D.R. and Porada-Rochoń, M., 2021. Impact of COVID-19 on the travel and tourism industry. Technological Forecasting and Social Change, 163, Article number: 120469. 